\title{
The Promise of NATO in the Construction of Cooperative Turkish-Greek Relations
}

\author{
H. TARIK OĞUZLU
}

This study seeks to explore the reasons why joint membership in NATO could not help Turkey and Greece resolve their long-standing territorial disputes in a problem solving win-win framework, based on the transformation of their realpolitik security cultures into nonrealpolitik security cultures. In undertaking this task, this article employs a partly theoretical and partly empirical perspective. The theoretical part assesses the expectations of various international relations theoretical accounts of the impact of international institutions/organizations on behaviors of states. There exist two main theoretical currents that aim at analyzing such a relationship. While rationalistic-institutionalist approaches confine the impact of international institutions/organizations only to behaviors of states, sociological-institutionalist approaches argue that institutional linkages not only shape and constrain states' behavioral strategies but also reconstruct their identities and interests. The empirical part of the essay analyses the Turkish-Greek interaction process within the framework of the Alliance from 1952 onwards, with particular attention paid to post-Cold War era developments. This article argues that the theoretical expectations of the above-mentioned approaches, particularly those of sociological-institutionalism and the neo-liberal version of rationalist-institutionalism, have been proved wrong. Turkey and Greece have neither succeeded in adjusting their behaviors to each other's needs and expectations, nor have they developed collective identities and interests that might in the final analysis have enabled them to form a security community in their region and solve their disputes once and for all.

\section{THEORETICAL EXPECTATIONS}

Rationalistic-institutionalist accounts of international relations assume that states interact with each other on the basis of their pre-given national interests and that international institutions/organizations/alliances have a minimal impact

H. Tarik Oğuzlu is a lecturer in the Department of International Relations at Bilkent University, Ankara. 
on their identities and interests. ${ }^{1}$ In the neo-realist version, such institutional platforms only serve as leverages or tools for states to utilize in their efforts to materialize their preconceived national interests. Their capability to make use of such institutional platforms will vary with their relative powers, mostly measured in material terms. The more powerful states will extract the most benefit from such institutions. ${ }^{2}$

Conceived of as such, the North Atlantic Treaty Organization (NATO) should primarily serve the interest of the United States, the most powerful country in the Alliance, as well as the members whose relative power within the Alliance exceeds that of other members. In this logic, states act in a Hobbesian kind of international anarchy that, in turn, makes cooperation between countries difficult. $^{3}$ The existence of international institutions does not decrease the suspicions of states interacting with each other. Concerns for relative-gains and cheating prevent states from trusting each other and from establishing long-term cooperative relationships. ${ }^{4}$

In neo-realist thinking, secondary powers join international institutions/ organizations out of necessity. There is only one choice ahead of them: they will either perish should they insist on the pursuit of their national interests on a unilateral basis, or they will join international organizations to be able to survive in the face of existential threats to their security. They conform to the normative requirements of international organizations, as long as the externally defined existential threats remain firm. Looking from this perspective, the transformative effects of international institutions on members, particularly those of latecomers, are at its minimum level, simply because states' interests are thought to be exogenous to the interaction process.

In the neo-liberal version of rationalist-institutional accounts, states form or join international institutions/organizations if they believe that they share some common interests and that they will only be able to realize them through cooperation, rather than by acting unilaterally. ${ }^{5}$ Their adherence to institutional cooperation will proceed parallel to their calculations that they will gain more than they lose. If this cost-benefit analysis shows the reverse, they will simply withdraw their commitments to such institutions. To this logic, states act within a Lockean kind of international anarchy, wherein the only impediment before cooperation involves concerns for cheating. ${ }^{6}$ The existence of international organizations helps assuage such concerns, and states cooperate to achieve their absolute gains.

To this logic, the degree of transformative effects of institutional membership is higher than the previous account expects. As long as states benefit from institutional cooperation, there will always be room for change in their identities and interests. However, institutional effects will overwhelmingly be limited to behavioral aspects. Such impacts will simply be regulative and measured in a cost-benefit mentality. Institutional relationships are, here, assumed to increase the level of transparency, confidence and interdependence among members. Gradually, members are presumed to grow more confident of each other's longterm intentions. Paralleling the increase in confidence and reliability, the likelihood of their future cooperation will increase since the negative 
consequences of the security dilemma situation will be minimized. Concerns for relative gains will gradually give way to concerns for absolute gains. ${ }^{7}$

According to this perspective, NATO has continued to operate in the 1990s as its members have subscribed to the view that the costs of dissolving NATO and establishing a new institutional framework will be higher than those of keeping NATO intact. ${ }^{8}$ NATO's institutional assets combined with the lower costs of having NATO on the ground account for the persistence of NATO as the main security organization of the Western international community in the post-Cold War era. ${ }^{9}$

Challenging rationalist-institutionalist insights, sociological-institutionalist accounts go one step further in arguing that institutional relationships will not only affect the particular strategies of states, and to some extent national interest, but also their identities. Thus, international structures are seen as consisting of both material and social elements and international institutions/organizations make up an important part of this social world. ${ }^{10}$ If states internalize the same constitutive norms of the same international organization, for instance, the liberal-democratic norms of NATO, then they end up with having a Kantian kind of international anarchy in which they can construct relationships based on friendship. In such relationships, concerns for absolute and relative gains no longer militate against the formation of cooperative relations since states will gradually define their national identities and interests by taking on each other's perspectives. In one way or the other, the boundaries of their self-identities will enlarge in such a way as to encompass others. Through a process of change, they will gradually give up their egoistic self-identities and adopt more altruistic collective identities. The formation of pluralistic security communities will thus become easier. ${ }^{11}$

Thought of in this way, international institutions stand for a group of countries, which come together alongside some collectively held norms and rules. ${ }^{12}$ For states wanting to join such international institutions, the main concern is ideational. What motivates them to ask for membership is neither the structural necessity to survive (as expected by neo-realists) nor the materially formulated cost-benefit analysis (as foreseen by neo-liberals), but the ideational concerns to legitimize/justify their national identity. ${ }^{13}$ The transformative effects of institutional membership/cooperation will be at its highest degree in this conceptualization. Long-term cooperation based on similar norms is seen as likely resulting in the convergence of national identities.

Within this conceptualization, NATO represents a pluralistic security community that came into existence in the wake of World War II out of the collectively held liberal and democratic principles among the members of the Western international community. ${ }^{14}$ The same logic can also be applied to the factors that seem to explain the persistence of the Alliance into the post-Cold War era. The fact that the Alliance has continued to exist in the absence of the existential Soviet threat can be attributed to NATO's ideationally defined new mission as to radiate the constitutive norms of the Western international community to the ex-communist countries of Central and Eastern Europe. ${ }^{15}$ 
All in all, in measuring the promise of NATO to contribute to the resolution of Turkish-Greek territorial disputes and to the maintenance of bilateral cooperation, one could argue that the expectations of sociological-institutionalism should hold more value than those of the rationalist-institutionalism. As the former theoretical approach assumes, Turkey and Greece should gradually converge their national identities and interests on the basis of the collectively held norms within the Alliance. They should gradually internalize the idea that it would be the most appropriate thing for them to hold on to the cooperative security approach and to settle their territorial disputes in a win-win framework by utilizing the peaceful methods of conflict resolution. Long-term cooperation on the basis of friendship should then be assured. They should also adapt their foreign and security policy doctrines to those of the Alliance and this should in turn prevent them from viewing each other as threats to their security. They should also share in the idea that living with territorial disputes within NATO, defined as a pluralistic security community, is no longer justified.

\section{THE NATO-TURKEY-GREECE TRIANGLE IN THE COLD WAR ERA}

\section{Reasons of Low Promise}

The role of the Alliance during the Cold War era in helping Greece and Turkey establish a long-term cooperative relationship did not prove promising for a number of reasons. First of all, the international/security identity of the Alliance did not necessitate a concerted and committed approach on the part of the United States, as the most powerful country in NATO, towards the resolution of their disputes. The NATO of the Cold War era was mainly a military alliance that came into existence around the US goal to contain Soviet communism. ${ }^{16}$ The Alliance did not have intra-alliance conflict-resolution mechanisms nor did it strongly emphasize the necessity of the resolution of territorial disputes among members as a precondition for the continuation of their membership. Turkey and Greece were simply admitted to membership because of their strategic and military contributions to the security interests of the Alliance vis-à-vis the Soviet Union. ${ }^{17}$ The rhetorical usage of normative arguments by the then US President, Truman, only aimed at convincing the reluctant US Congress and some European allies of the need to incorporate Turkey and Greece into the Alliance. $^{18}$

The Alliance's major area of concern remained Western and Central Europe and the security concerns resulting from the Eastern Mediterranean region did not receive the high attentions of the Alliance. Neither could the alliance devote a serious action to territorial disputes between Greece and Turkey, nor could a comprehensive approach be developed independent of the Cold War era strategic limitations. The technical and mechanical approach of the Alliance towards particular Turkish-Greek disputes did not contribute to their longlasting resolution. ${ }^{19}$ All Turkish-Greek disputes gained meaning in Washington only in terms of their possible implications on the struggle with the communist threat. ${ }^{20}$ The costs of sorting out comprehensive solution packages seemed to be higher than adopting a low-key attitude in an effort to defuse the tensions. The 
consideration was that it would have cost the Alliance the most if one of the parties felt aggrieved by a specific set of propositions of the Alliance and in turn left the club.

As long as their military commitment towards the defense of the EuroAtlantic security community against the Soviet threat was in place, the damaging repercussions of Turkish-Greek disputes over the Aegean Sea and Cyprus were somehow tolerated. The most important concern of the US governments during the Cold War era was to prevent Turkey and Greece from fighting each other, as well as to forestall Soviet attempts at meddling in any intra-NATO dispute. $^{21}$

Second, it was assumed by many NATO officials that doing so was a no-win proposition for the Alliance. It was even argued by some that if NATO proved its impartiality by maintaining an attitude of detached concern, Athens and Ankara would eventually realize that the alliance was not going to bail them out. Only then would they accept the responsibility for resolving their own differences. $^{22}$

Third, the dynamics of Turkey and Greece's relationship within the Alliance delayed, if not prevented, the process of democratization in both countries in the liberal-pluralist sense. ${ }^{23}$ The American governments of the Cold War era did not hide their desire to work with anti-left and royalist governments in Greece. They were also content with the military coups in Turkey, for they thought that the generals would keep Turkey within the orbit of the Alliance while eradicating the roots of communism and internal instability within the country. For example, while the European Union members froze Greece's association agreement during the 1967-74 junta era, US politicians and generals did not hesitate to visit Athens in order to lend legitimacy to the military regime. ${ }^{24}$ In the same manner, while European Union (EU) members suspended their relations with Turkey in the aftermath of the 1980 military coup, the Americans expressed their satisfaction with the regime and were able to strike a defense and economic cooperation agreement with Turkey in $1983 .^{25}$ The Americans thought that it would be easier for them to work with such governments because their very legitimacy emanated from the close relations with the Allies in NATO. To the Americans, such governments would be predisposed to take care of the interests of the Alliance, rather than pursing their own national priorities.

The fact that the socialization of Turkish and Greek elites into the Western mentality has mainly occurred through the hands of military elites in both countries has prevented the emergence and consolidation of liberal-democratic political elites. ${ }^{26}$

The fourth factor is that the US involvement in the bilateral Turkish-Greek disputes was predicated on the assumption that if the United States wanted to see a stable environment it would have to value the military balance between Greece and Turkey. Therefore, the amount of military sales and aid to either of them should not discriminate against the other. This approach decreased the credibility of the Alliance in both countries. The Turks tended to interpret the US ' 7 to 10 ' policy in terms of military sales to Turkey and Greece as the confirmation of the Turkish threat by the Americans. The fact that it was the 
Greeks who first pleaded with the Americans to adopt such a stance on the basis of the so-called menacing Turkish threat in the East, led the Turks to see the US logic towards the region as not impartial but lopsided in favor of Greece. Likewise, the Greeks would have also interpreted any inaction on the side of Americans as a sign of US acquiescence to Turkey's greater geopolitical value, as well as the legitimacy of Turkish arguments.

In fact, since the geostrategic position and military power of members does define their bargaining powers within the Alliance, Turkey's relatively more important status over Greece was supported. This status contributed to Greek thinking that any NATO-framed solution of the Cyprus and the Aegean disputes would be likely to favor Turkey at the expense of Greece. ${ }^{27}$ The need on the part of the Alliance to court Turkey, as the strategically more important country in the region, also inadvertently contributed to Turkey's resilience to accommodate with Greece on a cooperative basis, as well as to the perpetuation of a strategic rivalry between Greece and Turkey.

This feeling of necessity on the part of the West to incorporate Turkey into NATO was made clear by Leffer in his article on the accession of Turkey to NATO. ${ }^{28}$ The Americans valued Turkey's membership of NATO more than that of Greece. $^{29}$ This was so because, while the choice to elevate Turkey's status to membership of the Alliance from a bilateral security guarantee was radical in the eyes of the Americans, Greece's NATO membership on the other hand was regarded by the same Americans as the continuation of the vassal-lord relationship dating back to the Truman Doctrine of 1947. The Greek politicians of the time also regarded Greece's NATO membership as the continuation of the American patronage in Greece. ${ }^{30}$

Although it was argued that NATO in general, and the United States in particular, embraced a kind of low-key policy in order not to offend either Greece or Turkey, it is generally the case that Turkey appeared as the country that the Western community was more concerned about not antagonizing. For instance, when the Turkish government was somehow implicated in the September 1955 events in Istanbul, that took place in response to the news that Atatürk's house in Greece had been bombed by the Greeks, the US Secretary of State Dulles preferred to send identical telegrams to the leaders of both countries. When they heard this, the Greeks were infuriated. Since, they felt, the Turkish government held real responsibility for the bloody events in Istanbul, why should both countries be blamed? ${ }^{31}$

In the face of such pro-Turkish leanings from the Alliance, the major dilemma for Greek foreign policy-makers was how to strike a balance between the two competing strategies: to favor better Turkish-Greek relations in accordance with the strategic priorities of NATO on the one hand and to work for the realization of the unification of Cyprus with mainland Greece in accordance with Hellenistic ideology on the other. ${ }^{32}$ While rightist Greek governments leaned towards the first option, leftist ones tilted towards the second.

Fifth, right from the beginning of their membership of NATO, Turkey and Greece could never feel confident of whether the Article 5 security guarantee of the Alliance would be implemented automatically. The main reason behind their 
skepticism emanated from the way that some northern European countries approached Turkey and Greece's inclusion in the Alliance in the early 1950s. The fact that the allies came to a modus vivendi that the major responsibility to deal with particular Turkish-Greek disputes, as well as to extend security guarantees, would fall on the shoulders of the Americans, has eventually reduced the multilateral (and reinforced the bilateral) character of Turkey and Greece's institutional links with NATO.

While the United States, in conformity with the Alliance's strategic culture that its main threat comes from the Soviet Union as directed against the Western European members of the Alliance, wholeheartedly supported the EU's integration process and deployed the bulk of its military hardware along the central front of the alliance, the same United States preferred to have more bilateral relationships with Turkey and Greece defined by the special base and military aid agreements between itself on the one hand and Turkey and Greece on the other. ${ }^{33}$ When it was the case that the continuation of the Alliance's functions in the Eastern Mediterranean were made possible in the face of lingering Turkish-Greek problems, no need was aroused in Western circles to come up with serious and detailed proposals for a solution.

Sixth, the Turkish and Greek view that the United States and other major members of the Alliance did not care about their problems and were content with the maintenance of their conflictual relationship - at tolerable and manageable limits - seems to have put Greece and Turkey into a position in which they tended to vie for the resources and benefits of the Alliance in order to strengthen their bargaining positions vis-à-vis each other. The mentality of ' $I$ can better represent the Western interests in the region' inevitably pitted Turkey and Greece against each other as contenders and rivals. ${ }^{34}$

Both Greeks and Turks, in other words, consider that NATO undervalued their membership, albeit for different reasons. Paradoxically, the Alliance's present hands-off policy, although intended to project NATO's impartiality and encourage Athens and Ankara to settle their own differences, seems to be having the opposite effect. Both countries were led to interpret NATO's attitude as proof that the organization did not take them seriously and, accordingly, they see less prospects for rewards from the Alliance should they adopt more flexible policies, or penalties, should they fail to do so. It is also logical to suppose that what Greeks and Turks alike view as the relatively low priority accorded to the southeastern flank gives them little reason to place NATO priorities above their own when it comes to force planning and deployment, weapons procurement, and other aspects of their national defense policy.

Seventh, the American guarantee that the Alliance would defend them against the Soviets led Greece and Turkey to concentrate on more secondary foreign policy issues. When the first priority of their foreign policy, that is the security guarantee against the Soviet Union, was met by the Americans, Greece and Turkey became able to focus their attention more on their national issues. They did not feel the need to resolve their disputes as part of their efforts to resist communism. This has to a great extent led them to view the Alliance as a strategic instrument to serve their preconceived national interests, rather than as 
an institutional platform to obtain their collective security interests. ${ }^{35}$ They gradually came to believe that their support of the US efforts to contain the Soviet Union in Europe and the Eastern Mediterranean region would in return beget a holistic US support to every aspect of their security policy.

Examples of the two countries' instrumental usage of NATO's platforms for the pursuit of national interests abound. The first of such examples took place in 1954, when Greece argued for the establishment of a NATO patrol-boat base in the island of Leros, one of the Dodeconese islands. When NATO headquarters in Brussels favored this idea, Turkey rejected this plan by arguing that establishing this kind of base would be in breach of the 1923 Lausanne and 1947 Paris treaties, which stipulated that the Dodeconese islands would remain under Greek sovereignty provided that they be demilitarized. ${ }^{36}$

In this vein, the most important reason why Greece wanted to rejoin the Alliance in the late 1970s was to check Turkey's growing influence within NATO and to prevent the strategic balance in the Aegean Sea from favoring Turkey. Rather than helping Greece join forces with Turkey against the Soviet threat in the North, the Greek governments evaluated Greece's NATO membership as the main external security guarantee against any possible Turkish threat. This was made evident in the late 1970s when the Karamanlis government came to the conclusion that Turkey's continuing NATO membership in the absence of Greece would only damage Greek security interests. Indeed, one of the significant benefits of NATO membership to the Greek government is that it 'Europeanizes' to some extent the small but controversial US military presence in Greece. ${ }^{37}$

It is common to Greek and Turkish policies that both countries tried to control the strategic area of the Aegean Sea through the strategic and military plans of the Alliance. Turkey did not agree to the inclusion of Lemnos and other Aegean islands in the strategic plans of NATO and argued that if Turkey were given the operational control over at least half of the Aegean Sea, then it might better preserve the interests of the Alliance. In addition, Turkey made the case that fortification of the eastern Aegean islands would be in breach of the legal texts that regulate the status of those islands. By constantly vetoing the inclusion of the island of Lemnos in the planned military exercises of the Alliance in the region, Turkey hoped to prevent Greece from realizing her goals through NATO. $^{38}$

Greece, on the other hand, was captive to the same mentality and tried to demonstrate to the Allies, other than Turkey of course, that the fortification of the eastern Aegean islands would provide a strategic depth to Greece in defending Greece's (therefore the Alliance's) territory against threats coming from the North. The Defence Doctrine of 1985 made the essential points of the Greek strategy very clear. If those islands were fortified, the defense of NATO's interests against threats coming from either the North through land operations or from the Soviet's Fifth Escadra in the Aegean Sea would be realized in a much better way. However, one should not obscure the point that if NATO had agreed to these strategic considerations, Greece would have also been able to deter any Turkish threat coming from the East. Irrespective of the existence of any serious 
Turkish threat coming from the other side of the Aegean, the main underlying motivation behind Greece's attempts at selling out its 'defence in depth' strategy to the Alliance was to deter Turkey. ${ }^{39}$

Greece and Turkey have lobbied against each other as bitterly in Brussels as they did in Washington and have often used the same arguments in disputing NATO's allocation of infrastructure funds that they apply to the apportioning of US military assistance. They have objected to NATO's plans to provide infrastructure funds to each other. They have vetoed each other's shares. ${ }^{40}$

The deadlock in NATO has become so implacable that since 1984 Greece and Turkey have even vetoed each other's 'national chapters', the yearly inventory of forces assigned to NATO, which serves as a basis for NATO planning and also, in the past, for the Alliance's annual 'Comparison of NATO and Warsaw Pact Forces,' a document that for this reason was not issued after 1984.

From spring 1982 until the year 2000, Greek and Turkish forces did not participate in NATO's military exercises in the Aegean Sea together due to the controversy over the political status of the Lemnos/Limni Island. Greek-Turkish antagonism thus disfigured the military structure of the Alliance. ${ }^{41}$

For example, the Greek Defence Minister Papendraou, at a NATO defence ministers' meeting in December 1981, asked NATO to issue a formal security guarantee that it would protect its borders against Turkey. When the United States objected to this, Papandraou, as the defence minister of Greece, did not sign the final communiqué, the first such act seen in the history of the Alliance. ${ }^{42}$

Successive Greek governments also tried to get a formal security guarantee from the United States against Turkey while the two sides were discussing the details of the Defence and Economic Cooperation Agreement between the two countries. For example, in 1990, in response to US access to military bases and other facilities in Greece, the Greek government once again asked the United States to give the above-mentioned guarantee. ${ }^{43}$

When Turkey observed that the arms embargo placed on it was in part activated by the efforts of the Greek-American lobby in the US Congress and that the 7:10 ratio in American military aid to Turkey and Greece was in part forced by the attempts of the Greek government, then future NATO involvement in Turkish-Greek disputes became seen as unfavorable to Turkey. When the United States agreed to the continuation of the 7:10 ratio in the military aid delivered to both countries, it meant that the United States concurred with Greece that Turkey poses a threat to Greece in the Aegean Sea. In fact, it was Greece, which argued that the road to peace in the Aegean Sea would have to go through the balance of power between the arsenals of the countries and the US military aid shipped to them.

The same logic also applies to Greece. When the Greek governments witnessed NATO's passivity during the Cyprus crisis in 1974 and the subsequent de facto partition of the island, as well as NATO's refusal to include Lemnos Island in the military exercises in the Aegean Sea, an anti-NATO feeling might have developed in Greece in relation to the Alliance's involvement in TurkishGreek disputes. 
Eighth, while NATO met Greece and Turkey's number one security consideration, the flow of arms from the United States and other Western European members of the Alliance to Turkey and Greece contributed to the emergence and perpetuation of a security dilemma situation in the Aegean because they no longer shared in the collective interest to cooperate against the Soviet threat. ${ }^{44}$ Furthermore, when the Alliance armed Turkey with a view to helping it defend the Alliance's borders against the Soviet Union, the main purpose behind the flow of arms to Greece was to buttress Greece's capability to check the communist threat within the country. In this manner, the military disparity between Turkey and Greece became manifold as the Cold War years passed by. Thus the logic of NATO inadvertently contributed to the widening of the gap between Turkey and Greece in terms of their military capabilities.

Finally, under such conditions, the transparency that NATO's internal mechanisms provided were unable to prevent Turkey and Greece from perceiving each other's military instruments as threats. Indeed, the more Greece become aware of Turkey's superior military capabilities within NATO, the more it adopted an exclusive attitude towards Turkey. Greek fears of an expansionist Turkey were not lessened even though Greece could monitor Turkey's military capabilities through NATO channels. ${ }^{45}$ Indeed, their joint NATO membership revealed the power disparities between Greece and Turkey more acutely. Therefore, the intra-alliance mechanisms made it clear time and again that significant power differences exist between Greece and Turkey both in terms of their military potential and their representational force within the Alliance. Thought of in this way, their NATO membership has in fact contributed to the perpetuation of the realpolitik security culture in the Eastern Mediterranean region.

\section{THE NATO-TURKEY-GREECE TRIANGLE IN THE POST-COLD WAR} ERA

The expectations that NATO would be a more reliable and credible institution in regard to the resolution of the Turkish-Greek disputes continued to come to naught as the 1990s unfolded. Neither the changing institutional identity of the Alliance nor the changing structure of the international system has made NATO a credible actor in terms of Turkish-Greek disputes. The hope was that as the constraining effects of the bipolar international system came to an end with the dissolution of the Soviet regime, NATO would be more able to produce detailed proposals to resolve the particular Turkish-Greek disputes. The need not to antagonize either Turkey or Greece and the fear of losing either of them in the aftermath of a detailed NATO solution package has lost its credibility as the Alliance's need to rely on Turkey and Greece's military cooperation has decreased in the absence of the Soviet threat.

It was also hoped that the elevation of the Eastern Mediterranean region to the top place in the strategic focus of the Alliance would push the leading powers of NATO to actively work for the resolution of the Turkish-Greek disputes. The new conventional and non-conventional security threats, challenges and risks to 
the Alliance emanating from the Greater Middle Eastern region would necessitate a concerted NATO effort to help resolve the Turkish-Greek disputes. In a word, the loosening of the structural constraints of the Cold War era; the reconstruction of the Alliance's identity on the basis of the promotion of Western norms to the ex-communist countries; and the designation of the Eastern Mediterranean region as the new Central Front of the Alliance seemed to constitute the very factors why the new NATO would be more likely to adopt a bolder approach towards the final settlement of the Turkish-Greek disputes.

However, this article argues that these expectations have not come true in the post-Cold War era mainly because of the fact that NATO has started to lose its magnet status for Turkey and Greece to define their collective Western/ European identities. Gradually, the Alliance has ceased to become the platform under which Greece and Turkey could reach a collective Western/European identity that would have enabled them to accommodate their territorial disputes in a problem-solving win-win manner. The next section of the study is an attempt to analyze the reasons why NATO has increasingly lost its power of attraction in the eyes of these two countries that might have led them otherwise to end up with common identities and interests.

\section{General Factors of NATO's Low Promise/Credibility in the 1990s}

First, the new priority of the Alliance has been to enlarge and include the excommunist countries of the post-Soviet era in a political fashion, rather than to extend security guarantees of a collective defense organization to insecure places. By this logic, the Alliance has turned out to construct its main identity and mission in the 1990s on the basis of the idea that security could not be reached without the promotion of the normative ideational elements of the Western international community to the Central and Eastern European countries, or without engaging Russia in a cooperative mood. ${ }^{46}$ In one way or another, the Alliance has started to act as a pan-European cooperative security organization. This has partially reduced the attention paid by the Alliance to Turkish-Greek relations. Both countries have gradually become marginal to the new identity and missions of the Alliance.

Second, the erosion in the 'European' identity of the Alliance, mainly stemming from the division of the West into two, has given a boost to Greece and Turkey's efforts to join the EU in their goal to prove their Europeanness. During the 1990s, the European Union has been the institutional platform for Turkey and Greece both to prove their European identities and to work out their disputes. NATO has been transformed from being 'the only European' security organization into 'one of the European' security organizations during the postCold War era. ${ }^{47}$ Thought of in this way, the claim of the Alliance to embody the European identity has been seriously disputed by the EU's simultaneous enlargement process. This has become increasingly relevant as far as the promise of the Alliance to help Turkey and Greece develop a collective European identity is concerned, and has gradually diminished NATO's leverage over Turkey.

Third, the Alliance has gradually come under the domination of the United States as the process of 'Americanization' of NATO has sped up over the last 
decade. Parallel to the increase in the United States' relative power vis-à-vis the European members of the Alliance, the post-Cold War era NATO has mainly remained as a political instrument of the American government. As such, the Alliance has gradually turned out to become a state-centric platform for the Americans to enlist possible allies to their global-scale security initiatives and undertakings. Decisions about enlargement, defining the new missions of the Alliance, and determining the geopolitical boundaries of the Alliance have mainly reflected the concerns and priorities of the successive US governments in the 1990 s. $^{48}$

In this manner the United States has been able to preserve its prevailing power status in the continent, as well as keep the growing influence of the European Union members under its control. In an enlarged NATO, the number of proAmerican countries has increased with the incorporation of the Central and Eastern European countries.

There has somehow remained a tacit agreement between the Americans and the Europeans that the latter will recognize the 'global' and 'American' characters of the Alliance in return for the Alliance's military involvement in European security. The Europeans had to acquiesce to US involvement in European security, lest fears of renationalisation of security policies awaken before the Europeans themselves could complete their integration process in the areas of security, defense and foreign policies. ${ }^{49}$

In regard to the relevance of the Americanization of the Alliance to the nature of the Turkish-Greek interaction process, one could offer both optimistic and pessimistic views. As for the first, one could say the following. Interestingly enough, while the enlargement process of the Alliance to the Central and Eastern European Countries (CEECs) has diminished Turkey and Greece's relative positions within the Alliance, the emerging security concerns in the Balkans and the Greater Middle Eastern regions have once again made it clear that the nature of Turkish-Greek relations could seriously affect the performance of NATO as a security institution.

As the Alliance members have gradually come to the conclusion that new threats to the Alliance's security would be likely to come from the peripheries of the continent in the Balkans and the Greater Middle Eastern region, ${ }^{50}$ Turkey and Greece have been catapulted into a position of 'front states'. Thus, their significance within the Alliance has begun to increase from the second half of the 1990s onwards. Such geographical shifts in the Alliance's strategic perspectives initially held out the promise that NATO would finally start to deal with the Turkish-Greek disputes in a committed manner, since the lingering of such territorial disputes between Greece and Turkey could likely upset the Alliance's efforts to contribute to security in the region. ${ }^{51}$

As for pessimistic views, one could offer the following explanation. The more 'Americanized' the Alliance has become, the more difficult it has become for Turkey and Greece to reach a collective identity within NATO. This has been the case mainly for the reason that neither Turkey nor Greece has been happy with this development and both of them wanted the Alliance to preserve its European character and to act on a 'more multilateral and less unilateral' basis. 
Faced with increasing Americanization of the Alliance, Greece has given impetus to its Europeanization efforts and tried to identify its security interests with those of her partners within the EU, ${ }^{52}$ whereas Turkey, rebuked by the EU's gradual exclusionary/discriminatory policies, has had to improve the quality of her strategic security relations with the United States on a more bilateral and less multilateral basis. ${ }^{53}$

The Alliance has gradually lost its power of attraction in Turkish and Greek eyes, as these two littoral countries of the Aegean Sea have started to question the relevance of NATO to their overall security interests as well as links to the Western international community. Certainly such a NATO would hardly devote concerted attention to the Turkish-Greek territorial disputes.

The post-Cold War logic of the United States towards Turkey has made it more difficult for the Americans to actively encourage, or put pressure on, Turkey to accommodate Greek claims over the Aegean Sea and Cyprus. ${ }^{54}$ The fact that US need for Turkey's cooperation has tremendously increased in the 1990s has eroded the credibility of the United States/NATO to act as a promising actor in the resolution of Turkish-Greek disputes.

Evidence of Greece's alignment with the European Union, rather than the United States, has been abundant in the 1990s. During the wars in the territories of the former Yugoslavia, both Bosnia and Kosovo, Greece sided with the mainstream European policies. When the United States brought the issue of 'national missile defence' to the agenda of transatlantic relations, Greece again sided with her partners within the EU and argued against the rationale of US arguments. Lastly, Greece has decided to support Germany and France's points of view during the Iraqi crisis in the post-September 11 era. Rather than backing US rationale on the need to wage war against Saddam's regime, the Greeks have synchronized their views with those of the Germans and French by arguing for the utilization of the UN framework to the fullest extent possible. ${ }^{55}$

While Turkey has tried to reconstruct its European identity by actively participating in NATO's Mediterranean Dialogue, Greece has preferred to prove its Europeanness on the basis of active involvement in the European Union's Euro-Mediterranean Partnership Process. While Turkey has more easily identified its security interests in the Eastern Mediterranean region with those of the Alliance/Americans and seen the Western Mediterranean as marginal to its security concerns, Greece has preferred to adopt a more pro-EU profile in determining its security interests in the whole Mediterranean region and tried to act as the agent of the EU in the region. ${ }^{56}$

Fourth, the multilateral and transatlantic character of the Alliance has dramatically eroded as the European members of the Alliance have tried to establish autonomous 'European Foreign and Security Policy' and 'Common European Security and Defence Policy' structures within the European Union. This has seemingly led to a gradual lessening of the importance of the Alliance as an institutional platform in which the intra-member cooperation process could result in the mitigation of the anarchical effects of the international system. Alongside American efforts to globalize the Alliance and turn NATO into an organization on which they could rely in their efforts to compose US-led 
'coalitions of the willing', the European Union members have gradually grown dissatisfied with these developments and resolved to set into motion their own security institutions that would eventually help them meet their 'European-way' security concerns. ${ }^{57}$

NATO has begun to lose its collective defense organization character and gradually evolve into a collective security organization with the political functions of the Alliance being emphasized at the expense of the military and defense functions. ${ }^{58}$ This has mainly taken place as the Alliance members have begun finding it difficult to converge on collectively held security interests. The Cold War era degree of cohesion no longer exists during the post-Cold War years. The EU members have gradually found it difficult to abide by their Article 5 commitments towards Turkey because to them Turkey has increasingly appeared as a security liability rather than a security asset. The lessening of the Europeans' commitment to Turkey's security within NATO has reduced the credibility of the Alliance in Turkey's eyes.

Along with the deepening process within the EU, Greece seems to have shared in the belief that the EU should acquire an international actor status in as many areas as possible, most important of all being the areas of foreign and security policy. Today's Greece embraces a more European and less American foreign and security policy outlook in comparison to the Cold War times. The Greek governments of the 1990s have seen their links with the EU as the most important security guarantee against external threats, Turkey ranking the number one among them. ${ }^{59}$

Fifth, the promise of NATO has further decreased as both Turkey and Greece have approached the Alliance from an instrumental perspective. Greece's main concern has been to balance Turkey's growing influence and bargaining power vis-à-vis the United States through using the mechanisms of the Alliance, whereas Turkey's main motivation has been to consolidate/strengthen its European identity in the eyes of the EU members through working hard within NATO. Having felt rebuked by what it perceives as the EU's discriminatory and exclusionary attitude towards her membership aspirations, Turkey has tried to increase the quality of her NATO membership as a counter-reaction. However, neither of these strategies has led Greece and Turkey to share a collective/ European identity within NATO.

Throughout the 1990s, Turkey has increased her efforts to internalize the postCold War identity of the Alliance. It appears that there are two main factors that explain Turkey's penchant for internalizing the post-Cold War identity of the Alliance and adapt the basics of its security and defense policies to those of the Alliance. The first is the neo-realist connection. Even though the elimination of the Russian threat and Turkey's increasing military capabilities have both enabled Turkey to deal with the post-Cold War era security challenges and risks in more confident and efficient ways, Turkey has continued to value its link to NATO, for this has constituted the best possible way to secure the continuation of the American security guarantee to Turkey's security. Bilateral US-Turkey security relations, outside the framework of NATO, might in the final analysis have weakened Turkey's bargaining power vis-à-vis the Americans ${ }^{60}$ However, 
all in all, when the non-European character of the Alliance is combined with Turkey's increasing military capability to deal with threats to its security, the Alliance's leverage over Turkey has dramatically decreased.

The second factor is the ideational link. Faced with the European refusal of her membership of the EU and the gradual erosion of European commitments to Turkey's security, the internalization of NATO's post-Cold War era identity has seemed to be the only way for Turkey to register her European/Western identity. In addition to providing the Alliance with hard military power in risky locations on the world map, Turkey has also tried to adapt to the new changing identity of the Alliance by taking part in many of the NATO-led peacekeeping and peacemaking operations in and around Europe and by redesigning its defense policy in line with the defense reforms in NATO. Turkey has proved to be an ardent participant of the Partnership for Peace Program (PfP) and to this end hosted a PfP education center in Ankara. ${ }^{61}$

However, this process has only resulted in the increase of Turkey's bargaining power and significance in the eyes of the Americans rather than the confirmation of Turkey's European identity. The more Turkey's partners within the Alliance, particularly the Western European ones, have perceived Turkey's security role in terms of the Greater Middle Eastern region, rather than Europe, the more doubtful Turkey's Europeanness has become. Turkey's suspicions about European commitment to Turkey's security have become evident during the two Iraqi crises of 1990 and 2003. On both occasions, the European members of the Alliance have not adopted Turkey's security perceptions vis-à-vis Northern Iraq and have hesitated to assure Turkey that NATO would come to Turkey's help in case Iraq-originated concerns damage Turkey's territorial security. ${ }^{62}$

In conformity with the Cold War era logic, Greece has continued to see the Alliance from instrumental perspectives. To this end, the Greek governments of the 1990s have generally succeeded in embracing the post-Cold War security identity of the Alliance. Although much Greek effort has been invested in the Europeanization processes in the fields of foreign and defense policies, Greece has quickly come to the conclusion that NATO remains essential both to the security of the continent in general and the country in particular. The reasons for Greece to nevertheless continue to value her membership in NATO can be summarized as follows. First of all, Greece could not succeed in securing a formal territorial guarantee from the members of the EU and the Western European Union (WEU) vis-à-vis her relations with Turkey. Neither the European Union nor the Western European Union has become collective defense organizations of the NATO kind. The possibility that the European Union might decide to remain neutral in case of a war between Greece and Turkey certainly exists, as the negotiations between Turkey and the European Union regarding the use of NATO's assets by the EU in only EU-led military operations have demonstrated. ${ }^{63}$

Second, membership in NATO is valued for the single reason that Turkey would have to think twice before formulating her policy stance towards Greece if the latter is firmly nestled in the Western security structures, of which NATO is the most important one. In addition to membership in the EU and WEU, 
Greece's membership in NATO is thought of as contributing to Greece's soft power vis-à-vis Turkey. The concern that the Americans respect the military balance in the region and do not contribute to Turkey's armament in such a way that might unbalance the military equality between Greece and Turkey seems to have shaped the Greek rationale towards NATO. ${ }^{64}$

It has been a significant component of Greece's post-Helsinki strategy towards Turkey that Greece relies on its NATO membership and the preservation of the balance of power in the Aegean Sea in her efforts to prevent Turkey from undertaking any fait accompli either in the Sea or in Cyprus. The fear has been that if Greece did not counterbalance Turkey through such means, Turkey might abuse Greece's cooperative approach towards Turkey within the framework of the European Union's accession process. The way to prevent Turkey from interpreting Greece's cooperative gestures along the EU accession process as evidence of Greece's weakness, has been to continue to value Greece's links to the Alliance. ${ }^{65}$

A significant development in this regard is that Greece has been vociferously arguing for the transformation of the Alliance into a collective security organization in the post-Cold War era. It seems that there is a positive relationship between Greece's efforts in this regard and the degree of Turkey's characterization of Greece's main external threat. The more Turkey has remained Greece's main security threat, the more Greece has advocated the transformation of the Alliance into a collective security organization. Given that the probability of Turkey being cast as a threat to Greece's security is at an alltime low due to Turkey's membership in 'NATO the collective defence organisation' and that this NATO has no internal mechanisms to resolve intraalliance territorial disputes, Greece could not benefit from this NATO against Turkey. However, in a NATO, which is restructured as a collective security organization, membership would not imply that a member state can never be labeled a future security threat. Not based on a clear-cut insiders/outsiders framework, a current member of 'NATO the collective security organisation' can be categorically viewed as a security threat in the future if the majority of the members view them as such. ${ }^{66}$

\section{CONCLUSION}

Even though the article has thus far argued that the role of the Alliance in the consolidation of long-term cooperative Turkish-Greek relations, based on the construction of a collective identification process in and around the Aegean Sea, has been marginal, one should nevertheless admit that NATO has played some positive roles as well.

Though a full discussion of these occasions is beyond the scope of this study, it is worth mentioning that their NATO membership has at least prevented Greece and Turkey from openly fighting each other. In this sense, NATO has been successful in the prevention of direct military conflict between the sides. It is entirely possible that Turkey and Greece could have become involved in a military clash had they not been members in NATO. However, one needs to 
make clear that it has most of the time been the last-minute involvement of high level American figures, rather than the Alliance itself, which has prevented Greece and Turkey from engaging with each other.

Turkey and Greece were also able to maintain a negative peace in their region for about half a century due to their development of a crisis-management culture within the Alliance framework. For example, NATO's role in the dissipation of crises has been evident during the recent Imia/Kardak crisis. Had they not cared about their requirements within the Alliance and had they not developed crisiscontrol regimes in the Aegean Sea over the last three decades, they might have easily fought each other. The latest Imia/Kardak crisis attests to the fact that an embryonic crisis-control regime is in the offing in the Aegean Sea. Neither country mobilized their air forces but, instead, made operational their navies, which are slow and easy to control. ${ }^{67}$

NATO has also offered these countries in the 1990s a good opportunity to cooperate in regional security initiatives. In September 1998, Greece and Turkey, along with Italy, established the Balkans rapid deployment task force known as the Southeast European Brigade, to be used for peacekeeping operations in the region, as well as for potential deployment in nearby areas such as the Black Sea, in the event of a crisis. During the NATO war against Yugoslavia in spring 1999, the Greek and Turkish military forces cooperated regularly, especially to deliver supplies, reinforcements, and humanitarian assistance to the front lines in Macedonia and in Albania near the Kosovo border.

However, all in all, the new identity of the Alliance has sent mixed signals as to the promise of NATO in the resolution of the Turkish-Greek problems. While the emerging collective security identity of the Alliance at the expense of its collective defense identity and its concentration on the enlargement to the CEECs seem to have led to a decrease in the attention, which the major powers of the Alliance should have shown to Turkish-Greek disputes, the new directions of the Alliance's strategic focus seem to have increased the risks of any inadvertent military clash between these two countries to the realization of NATO's interests in the Greater Middle Eastern region.

As NATO has turned out to become less cohesive with the inclusion of new members; a more political, less military-oriented collective security entity; more non-European with the elevation of the Greater Middle Eastern region to the most important area of concern; and more Americanized with the growing influence of the United States in the decision-making mechanisms, the less credible and less promising the Alliance has become in terms of the resolution of the Turkish-Greek disputes.

\section{NOTES}

1. Kenneth Waltz, 'Structural Realism After the Cold War', International Security, Vol. 25, No. 1 (Summer 2000), pp. 5-41, p. 24; John J. Mearsheimer, 'Back to the Future Instability in Europe After the Cold War', International Security, Vol. 15, No. 1 (1990), pp. 5-56.

2. John J. Mearsheimer, 'The False Promise of International Institutions', International Security, Vol. 19, No. 3 (Winter 1994-95), pp. 5-49. 
3. Alexander Wendt, Social Theory of International Politics (Cambridge: Cambridge University Press, 1999).

4. Joseph M. Grieco, 'Anarchy and the Limits of Cooperation: A Realist Critique of the Newest Liberal Institutionalism', in David. A. Baldwin, Neorealism and Neoliberalism: The Contemporary Debate (New York: Columbia University Press, 1993), pp. 116-40; Robert Powel, 'Absolute and Relative Gains in International Relations Theory', American Political Science Review, Vol. 85, No. 4 (Dec. 1991), pp. 701-26.

5. Robert O. Keohane and Lisa L. Martin, 'The Promise of Institutional Theory', International Security, Vol. 20, No. 1 (Summer 1995), pp. 39-51; Robert. O. Keohane, After Hegemony: Cooperation and Discord in World Political Economy (Princeton, NJ: Princeton University Press, 1984), p. 246.

6. Robert Axelrod and Robert O. Keohane, 'Achieving Cooperation under Anarchy: Strategies and Institutions', World Politics, Vol. 38, No. 1 (Oct. 1985), pp. 226-54; Alexander Wendt, Social Theory of International Politics (Cambridge: Cambridge University Press, 1999).

7. Duncan Snidal, 'Relative Gains and the Pattern of International Cooperation', in David. A. Baldwin, Neorealism and Neoliberalism: The Contemporary Debate, p. 208.

8. Robert M. McCalla, 'NATO's Persistence after the Cold War', International Organisation, Vol. 50, No. 3 (1996), pp. 445-75.

9. Celeste A. Wallander, 'Institutional Assets and Adaptibility: NATO After the Cold War', International Organisation, Vol. 54, No. 4 (2000), pp. 705-35.

10. Alexander Wendt and Peter J. Katzenstein, 'Norms, Identity, Ronald L. Jepperson and Culture in National Security', in Peter J. Katzenstein, The Culture of National Security (New York: Columbia University Press, 1996), pp. 33-75; Timothy Dunne, 'The Social Construction of International Society', European Journal of International Relations, Vol. 1, No. 3, pp. 367-89; Marta Finnemore, 'International Organisations as Teachers of Norms: The United Nations educational, scientific, and the cultural organisation and science policy', International Organisation, Vol. 47, pp. 565-97.

11. Emanuel Adler and Michael Barnett, Security Communities (Cambridge: Cambridge University Press, 1998).

12. Frank Schimmelfennig, 'International Socialisation in the New Europe: Rational Action in an Institutional Environment', European Journal of International Relations, Vol. 6, No. 1 (2000), pp. 109-39.

13. Ian Hurd, 'Legitimacy and Authority in International Relations', International Organisation, Vol. 53, No. 2 (Spring 1999), pp. 379-409.

14. Thomas Risse-Kappen, 'Democratic-Peace-Warlike Democracies? A Social Constructivist Interpretation of the Liberal Argument', European Journal of International Relations, Vol. 1, No. 4 (1995), pp. 491-517.

15. Martin A Smith and Grahem Timmins, 'The EU, NATO, and The Extension of Institutional Order in Europe', World Affairs, Vol. 163, No. 2 (2000), pp. 80-90; Boyka Stefanova, 'The Baltic States' Accession to NATO and the European Union: An Extension of the European Security Community', Journal of International Relations and Development, Vol. 5, No. 2 (2002), pp. 156-81.

16. Richard Rupp, 'NATO 1949 and NATO 2000: From Collective Defense toward Collective Security', The Journal of Strategic Studies, Vol. 23, No. 3 (2000), pp. 154-76.

17. Bruce R. Kuniholm, The Origins of the Cold War in the Near East: Great Power Conflict and Diplomacy in Iran, Turkey and Greece (Princeton, NJ: Princeton University Press, 1980).

18. Robert Frazier, 'Acheson and the Formulation of the Truman Doctrine', Journal of Modern Greek Studies, Vol. 17, No. 2 (1999), pp. 229-51.

19. Montegale Stearns, Entangled Allies: U.S. Policy Towards Greece, Turkey, and Cyprus (New York: Council on Foreign Relations Press, 1992), pp. 8-24.

20. Ivar-Andre Slengesol,. 'The United States and the 1974 Cyprus Crisis', Mediterranean Quarterly, Vol. 11, No. 2 (2000), pp. 96-129.

21. M. James Wilkinson, 'The United States, Turkey and Greece - Three's A Crowd', in Morton Abromowitz, Turkey's Transformation and American Policy (New York: The Century Foundation Press, 2000), pp. 185-218.

22. Stearns, Entangled Allies, pp. 8-24.

23. Petros Ilias Vamvakas, 'States in Transition and Defensive Alliances: Greece and Turkey in NATO', unpublished Ph.D. thesis, Boston University Graduate School of Arts and Sciences, 2001.

24. Constantine P. Danopoulos, 'Military Professionalism and Regime Legitimacy in Greece: 19671974', Political Science Quarterly, Vol. 98, No. 3 (1983), pp. 485-507. 
25. İhsan Dağı, 'Human Rights and Democratisation: Turkish Politics in the European Context', Journal of Southeast European and Black Sea Studies, Vol. 1, No. 3 (2001), pp. 51-68.

26. Ali L. Karaosmanoğlu, 'Officers: Westernisation and Democracy', in Metin Heper, Ayse Öncü and Heinz Kramer, Turkey and the West: Changing Political and Cultural Identities (London: I.B. Tauris, 1993), pp. 19-34.

27. Victor Papacosma, 'Greece and NATO', in Lawrance Kaplan, Robert W. Clawson and Raimondo Luraghi, NATO and the Mediterranean (Delaware, DE: SR Scholarly Resources Inc, 1985), pp. 189-213.

28. Melvyn Leffer, 'Strategy, Diplomacy, and the Cold War: The United States, Turkey, and NATO, 1945-1952', The Journal of American History, Vol. 71, No. 4 (1985), pp. 807-25.

29. Marialena Conalis-Kontas, 'U.S. Foreign Policy in the Settled Post-Cold War Period: The Cases of Greece and Turkey' in Panayotis J. Tsakonas and Aistide D. Caratzos (eds), Greece and Turkey After the End of the Cold War (New York: Christodoulos K. Yiallourides Publications), pp. 385-405.

30. Keith Legg and John M. Roberts, Modern Greece: A Civilisation on the Periphery (Boulder, CO: Westview Press, 1997), pp. 55-71.

31. Stearns, Entangled Allies.

32. Van Coufoudakis, 'Greek-Turkish Relations, 1973-1983: The View from Athens', International Security, Vol. 9, No. 4 (1985), pp. 185-217.

33. James Kurth, 'The Next NATO Building an American Commenwealth of Nations', The National Interest, No. 65 (Fall 2001), pp. 5-16.

34. M. Fatih Tayfur, 'Akdenizde Bir Adanın Kalın Uçlu Bir Kalemle Yazılmıs Hikayesi: Kıbrıs', in Oktay Türel, Akdenizde Bir Ada: KKTC'nin Varoluş Öyküsü (Ankara: Imge, 2002), pp. 13-51.

35. Ronald Krebs, 'Perverse Institutionalism: NATO and the Greco-Turkish Conflict', International Organisation Vol. 53, No. 2 (1999), pp. 343-77; Charles L. Glasser, 'The Security Dilemma Revisited', World Politics, Vol. 50 (Oct. 1997), pp. 171-201.

36. John O. Iatrides, 'NATO and Aegean Disputes', in Aldo Chircop, André Gerolymatos and John O. Iatrides, The Aegean Sea After the Cold War Security and Law of the Sea Issues (London: Macmillan Press, 2000), pp. 32-46.

37. Ibid.

38. Ali. L. Karaosmanoğlu, 'Turkey and NATO', NATO's Sixteen Nations (Dec. 1989), pp. 46-51; Ali. L. Karaosmanoğlu, 'Turkey and the Southern Flank: Domestic and External Contexts', in John Chipman (ed.), NATO's Southern Allies: Internal and External Challenges (London: Routledge, 1988), pp. 85-118.

39. Van Coufoudakis, 'The Essential Link Greece in NATO', NATO's Sixteen Nations (July 1988), pp. 35-44; Ioannis Varvitsioitis, 'The Defence of Greece', NATO's Sixteen Nations, No. 5 (1992), pp. 11-14; Thanos Veremis, 'Greece and NATO: Continuity and Change', in NATO's Southern Allies (1988), pp. 236-86.

40. James Brown, Delicately Poised Allies: Greece and Turkey Problems, Policy Choices and Mediterranean Security (London: Brassey's, 1991).

41. Michael N. Schmitt, 'Ege'de Endişe Türk-Yunan Anlaşmazlığı', Deniz Kuvvetleri Dergisi, No. 568 (1997), pp. 1-25.

42. Panoyote E. Dimitras, 'Greece: A New Danger', Foreign Policy, Vol. 78, No. 19 (1985), pp. $134-50$.

43. Ioannis Staphopoulos, 'Greece and the Mediterranean - Strategic Assessments and Consideration', NATO's Sixteen Nations, No. 5 (1992), pp. 16-19.

44. Krebs, 'Perverse Institutionalism', pp. 343-77; Charles L. Glasser, 'The Security Dilemma Revisited', pp. 171-201.

45. Krebs, 'Perverse Institutionalism', pp. 343-77.

46. Frank Schimmelfennig, 'NATO Enlargement: A Constructivist Explanation', Security Studies, No. 99 (1999), pp. 198-234.

47. Gülnur Aybet, A European Security Architecture after the Cold War: Questions of Legitimacy (Hampshire: Macmillan Press, 2000).

48. Christopher Layne, 'US Hegemony and the Perpetuation of NATO', The Journal of Strategic Studies, Vol. 23, No. 3 (2000), pp. 59-92; Stuart Croft, 'The EU, NATO and Europeanisation: The Return of Architectural Debate', European Security, Vol. 9, No. 2 (2000); Stanley R. Sloan, 'US Perspectives on NATO's Future', International Affairs, Vol. 71, No. 2 (1995), pp. 217-31.

49. Robert Art, 'Why Western Europe Needs the United States and NATO', Political Science Quarterly, Vol. 111, No. 1 (1996), pp. 1-39; John S. Duffield, 'NATO's Functions after the Cold War', Political Science Quarterly, Vol. 109, No. 5 (1994/95), pp. 763-87. 
50. John Sitilides, 'U.S. Policy in the Eastern Mediterranean: Managing the Greece, Turkey, Cyprus Triangle', Western Policy Center Issue Briefings, Washington, DC: Western Policy Center, 2001; Stephen R Norton,. 'U.S. Policy in Greece, Turkey, and Cyprus: Prospects for Building Opportunities and Avoiding Crises in the Eastern Mediterranean', Western Policy Center Issue Briefings, 2001; D. İhsan Dağ1, 'Human Rights and International Security: The Challenge for NATO in the Mediterranean', Mediterranean Quarterly, Vol. 13, No. 3 (Fall 2002), pp. 119-34; John Roper, 'NATO's New Role in Crisis Management', The International Spectator, Vol. 34, No. 2 (1999), pp. 51-61.

51. F. Stephen Larrabee, 'US Policy toward Cyprus and the Eastern Mediterranean: Changing Strategic Perspectives after the Cold War', in Susanne Baier-Allen (ed.) Looking into the Future of Cyprus-EU Relations (Baden-Baden: Nomos Verlagsgesellschaft, 1999), pp. 231-247.

52. Pnangiotis C. Ioakimidis, 'The Europeanisation of Greece's Foreign Policy', in Achlleas Mitsos and Elias Mossialos, Contemporary Greece and Europe (Aldershot: Ashgate, 2000), pp. 359-72; C. Ioakimidis, 'The Europeanisation of Greece: An Overall Assessment', South European Society \& Politics, Vol. 5, No. 2 (Autumn 2001), pp. 73-94.

53. Ekavi Athanassopoulou, 'American-Turkish Relations since the End of the Cold War', Middle East Policy, Vol. 8, No. 3 (2001), pp. 144-64; George S. Harris, 'US-Turkish Relations,' in Alan Makovsky and Sabri Sayar1, Turkey's New World: Changing Dynamics in Turkish Foreign Policy (Washington DC: The Washington Institute for Near East Policy, 2000), pp. 189-202.

54. Kemal Kirişçi, 'US-Turkish Relations: from uncertainty to closer ties', Insight Turkey, Vol. 2, No. 4 (2000), pp. 37-63; Bruce Kuniholm, 'Turkey's Accession to the European Union: Differences in European and US Attitudes, and Challenges for Turkey', Turkish Studies, Vol. 2, No. 1 (2001), pp. 25-53.

55. Official Web Page of the Greek Foreign Ministry, available at http://www.mfa.gr

56. M. Fatih Tayfur, 'Security and Cooperation in the Mediterranean', Perceptions, Vol. 5, No. 3 (2000); İlter Turan. 'Mediterranean Security In the Lights of Turkish Concerns', Perceptions, Vol. 3, No. 2 (1998); P.C. Ioakimidis, 'Greece, the European Union and Southeastern Europe: Past Failures and Future Prospects', in Van Coufadakis, Harry J. Posomosades and Andre Gerolymatos, Greece and the New Balkans: Challenges and Opportunities (New York: Pella Publishing Company, 1999), pp. 169-91; P.C. Ioakimidis, 'The Role of Greece in the Development of EC Mediterranean Policy', in Richard Gillespie, Mediterranean Politics, Volume 2 (London: Pinter, 1996 ), pp. 67-81.

57. Henrik Larsen, 'The EU: A Global Military Actor?', Cooperation and Conflict, Vol. 37, No. 3 (2002), pp. 283-302; Helene Sjursen, 'New Forms of Security in Europe', Arena Working Papers, No. 4, 2001; Ian Manners, 'European 'Security” Union' From Existential Threat to Ontological Security', Working Paper, Copenhagen Peace Research Institute, 2002; Ivo H. Daalder, 'Are the United States and Europe heading for divorce', International Affairs, Vol. 77, No. 3 (2001), pp. 553-67; François Heisbourg, 'The European-US Alliance: Valedictory Reflections on Continental Drift in the Post-Cold War era', International Affairs, Vol. 68, No. 4 (1992), pp. 665-78; Joseph S. Nye Jr., 'The US and Europe: Continental Drift?', International Affairs, Vol. 76, No. 1 (2000), pp. 51-9.

58. David S. Yost, 'The New NATO and Collective Security', Survival, Vol. 40, No. 2 (1998), pp. 135-60; Rebecca Moore, 'NATO's Mission for the New Millennium: A Value-Based Approach to Building Security', Contemporary Security Policy, Vol. 23, No. 1 (2002), pp. 1-34.

59. Yannis A. Stivachtis, 'Greece and the Eastern Mediterranean Region Security considerations, the Cyprus imperative and the EU option', in Thomas Diez, The European Union and the Cyprus Conflict: Modern Conflict and Postmodern Union (Manchester: Manchester University Press, 2002), pp. 35-53.

60. Ali L. Karaosmanoğlu, and Mustafa Kibaroğlu, 'Defense Reform in Turkey', in Istvan Gyarman et al., Post-Cold War Defense Reform: Lessons Learned in Europe and the United States (New York: Brassey's, 2002), pp. 131-64.

61. Ibid.

62. Ali L. Karaosmanoğlu, 'Avrupa Güvenlik ve Savunma Kimliği Açısından Türkiye-Avrupa Birliği İlişkileri’, Doğu-Batı, Vol. 4, No. 14 (2001), pp. 156-66; Ali L. Karaosmanoğlu, 'Transatlantik Çatlağı: Değişen Kimlikler', Doğu-Batı, Vol. 6, No. 3 (2003), pp. 175-83; Ali L. Karaosmanoğlu, 'Europe's Geopolitical Parameters', in S. Togan and V.N. Balasubramanyan, Turkey and Central Eastern European Countries in Transition: Towards Membership of the EU (New York: Palgrave, 2001), pp. 271-89.

63. Antonio Missiroli, 'EU-NATO Cooperation in Crisis Management: No Turkish Delight for ESDP', Security Dialogue, Vol. 33, No. 1 (2002), pp. 9-26. 
64. Fotios Moustakis and Michael Sheehan, 'Greek Security Policy after the Cold War', Contemporary Security Policy, Vol. 21, No. 3 (2000), pp. 95-115; Panayotis J. Tsakonas, 'Post-Cold War Security Dilemmas Greece in Search of the Right Balancing Recipe', in Tsakonas and Caratzos, Greece and Turkey After the End of the Cold War, pp. 145-59.

65. Theodore Couloumbis and Kostas Ifantis, 'Altering the Security Dilemma in the Aegean: Greek Strategic Options and Structural Constraints - A Realist Approach', The Review of International Affairs, Vol. 2, No. 2 (2002), pp. 1-25.

66. Victor S. Papacosma, 'NATO, Greece and the Balkans in the Post-Cold War era', in Coufadakis, Posomosades and Gerolymatos, Greece and the New Balkans: Challenges and Opportunities, pp. 47-67.

67. Michael Robert Hickok, 'The Imia/Kardak Affair, 1995-1996: A Case of Inadvertent Conflict', European Security, Vol. 7, No. 4 (1998), pp. 118-36. 
Copyright of Review of International Affairs is the property of Frank Cass \& Company Ltd. and its content may not be copied or emailed to multiple sites or posted to a listserv without the copyright holder's express written permission. However, users may print, download, or email articles for individual use. 